\title{
Remarkably similar response to gold therapy in HLA identical sibs with rheumatoid arthritis
}

\author{
L B A VAN DE PUTTE, 'F SPEERSTRA, 'P L C M VAN RIEL.' \\ A M Th BOERBOOMS, ${ }^{1}$ P J I VAN'T PAD BOSCH, ${ }^{3}$ AND P REEKERS
}

From the Departments of ${ }^{1}$ Rheumatology and ${ }^{2}$ Transplantation Serology, University Hospital St Radboud. and ${ }^{3}$ St Maartens Clinic, The Netherlands

SUMMARY Two pairs of sibs with definite rheumatoid arthritis responded in a remarkably similar if way to parenteral gold therapy, in terms of both toxicity and efficacy. Both pairs proved to be $\vec{N}$ HLA identical. One of the pairs possessed the HLA antigens B8 and DR3, which have been $\vec{\circ}$ associated with both drug toxicity and excellent clinical response. The other pair did not possess $\varnothing$ either of these antigens, suggesting that the reaction to gold therapy in patients with rheumatoid arthritis may be determined by other HLA or genetic factors coded for by chromosome 6 , or both.

Key words: HLA antigens.

Parenteral gold is still a cornerstone of drug treatment of rheumatoid arthritis (RA). Disadvantages of the drug are its frequent toxicity and its ineffectiveness in some patients. Recently, associations with certain HLA antigens have indicated that genetic factors have a role in both gold toxicity and effectiveness. ${ }^{1-4}$ HLA antigens involved include B8 and DR3 in gold toxicity and DR3 in predicting excellent response to the drug. ${ }^{1-3}$ Another study found a relation between the absence of antigen $A 3$ and the simultaneous presence of antigen DR 4 and poor response to parenteral gold. ${ }^{4}$

In the present report we describe two pairs of sibs with rheumatoid arthritis who responded in a remarkably similar way to parenteral gold therapy, in terms of both toxicity and clinical response, one of the sib pairs doing so during two subsequent courses of parenteral gold. Tissue typing showed that both pairs of sibs were HLA identical; whereas one pair of sibs was HLA-B8 and DR3 positive, the other one did not possess HLA antigens known to be associated with toxicity or clinical response. This observation suggests that other HLA antigens or genetic factors coded for by chromosome 6 , or both

Accepted for publication 5 June 1986.

Correspondence to Dr P L C M van Riel, Department of Rheumatology, University Hospital St Radboud, Postbus 9101. 6500 HB Nijmegen. The Netherlands. may have a role in the response to parenteral gold io patients with rheumatoid arthritis.

\section{Patients and methods}

In a large study on families with multiple cases of $\stackrel{\mathbb{Q}}{\varrho}$ rheumatoid arthritis we detected two sib pairs with $\overrightarrow{\hat{0}}$ definite rheumatoid arthritis according to the re- 3 vised American Rheumatism Association diagnostic criteria, ${ }^{5}$ who responded in a remarkably similar way to parenteral gold therapy with aurothioglucose. Toxicity was monitored by regular questionnaire, physical examination, blood counts, and urine analysis. Response to gold therapy was evaluated according to a modification of a recently published scoring system for patients with rheumatoid arthritis. ${ }^{36}$ Parameters used in this evaluation are the duration of morning stiffness, observer assessment, $\frac{7}{0}$ haemoglobin, and erythrocyte sedimentation rate (ESR). HLA typing was done with standard o National Institute of Health microlymphocytotoxicity techniques for HLA-A, B, C, and DR antigens. ㅇ Sera were partly of local origin, all sera being $\omega$ standardised against the 8th and 9th International Histocompatibility Workshop sera.

\section{Case reports}

All four patients had a symmetrical polyarthritis. 
Table 1 Patient characteristics

\begin{tabular}{|c|c|c|c|c|}
\hline & \multicolumn{2}{|c|}{ Sib pair I } & \multicolumn{2}{|c|}{ Sib pair II } \\
\hline & $\begin{array}{l}\text { Patient } \\
\text { No } I\end{array}$ & $\begin{array}{l}\text { Patient } \\
\text { No } 2\end{array}$ & $\begin{array}{l}\text { Patient } \\
\text { No } 3\end{array}$ & $\begin{array}{l}\text { Patient } \\
\text { No } 4\end{array}$ \\
\hline Sex & $\mathbf{F}$ & $\mathbf{F}$ & $\mathbf{M}$ & $\mathbf{F}$ \\
\hline Age at onset of RA & 53 & 54 & 53 & 71 \\
\hline Joint erosions & \pm & + & + & + \\
\hline Nodules & - & - & - & - \\
\hline Seropositive & + & + & - & + \\
\hline ANA ${ }^{*}$ & - & - & - & + \\
\hline HLA haplotypes & \multicolumn{2}{|c|}{ A10Bw21DR3/A3B40DR4 } & \multicolumn{2}{|c|}{ A2B7DR4/A2B18DR4 } \\
\hline
\end{tabular}

*ANA = antinuclear antibodies.

Table 2 Reaction to parenteral gold

\begin{tabular}{|c|c|c|c|c|c|c|}
\hline & \multicolumn{2}{|l|}{ Sib pair I } & \multicolumn{2}{|l|}{ Sib pair $I^{*}$} & \multicolumn{2}{|l|}{ Sib pair $\mathrm{II}^{+}$} \\
\hline & Patient No $l$ & Patient No 2 & Patient No 3 & Patient No 4 & Patient No 3 & Patient No 4 \\
\hline Toxicity type & Dermatitis & Dermatitis & $\begin{array}{l}\text { Dermatitis. } \\
\text { stomatitis }\end{array}$ & Dermatitis & Dermatitis & Dermatitis \\
\hline At time & $5 \mathrm{wk}$ & $3 \mathrm{mo}$ & $4 \mathrm{mo}$ & $8 \mathrm{mo}$ & $5 \mathrm{mo}$ & $9 \mathrm{mo}$ \\
\hline At dose (mg) & 250 & 850 & 1200 & 1100 & 500 & 800 \\
\hline Response type & Excellent & Excellent & Moderate & Moderate & Moderate & Moderate \\
\hline At time (months) & 2 & 3 & $3-4$ & 4 & 6 & 4 \\
\hline$a^{s}$ & $\begin{array}{l}13 \cdot 5 \\
13 \cdot 1\end{array}$ & $\begin{array}{l}11 \cdot 8 \\
12 \cdot 1\end{array}$ & $\begin{array}{l}14 \cdot 2 \\
13 \cdot 1\end{array}$ & $\begin{array}{l}12 \cdot 1 \\
10 \cdot 5\end{array}$ & $\begin{array}{l}12 \cdot 7 \\
13 \cdot 1\end{array}$ & $\begin{array}{l}11.5 \\
11.5\end{array}$ \\
\hline $\operatorname{ESR}(\mathrm{mm} / 1 \mathrm{st} \mathrm{h})$ & & & & & & \\
\hline $\begin{array}{l}\text { a } \\
\mathbf{b}\end{array}$ & $\begin{array}{l}36 \\
19\end{array}$ & $\begin{array}{l}66 \\
21\end{array}$ & $\begin{array}{l}33 \\
10\end{array}$ & $\begin{array}{l}30 \\
15\end{array}$ & $\begin{array}{l}59 \\
28\end{array}$ & $\begin{array}{l}25 \\
13\end{array}$ \\
\hline $\mathrm{MS} \|(\min )$ & & & & & & \\
\hline $\begin{array}{l}a \\
b\end{array}$ & $\begin{array}{r}120 \\
15\end{array}$ & $\begin{array}{r}120 \\
0\end{array}$ & $\begin{array}{r}120 \\
15\end{array}$ & $\begin{array}{r}120 \\
10\end{array}$ & $\begin{array}{r}15 \\
0\end{array}$ & $\begin{array}{r}15 \\
0\end{array}$ \\
\hline $\begin{array}{l}\text { Doctor's } \\
\text { assessment }\end{array}$ & Excellent & Excellent & Excellent & Excellent & Good & Excellent \\
\hline
\end{tabular}

${ }^{*}$ First treatment episode.

tSecond treatment episode.

$\ddagger$ SI conversion: $\mathrm{Hb} \mathrm{g} / 100 \mathrm{ml} \times 10=\mathrm{g} / 1$.

$\$ a=a$ the onset of therapy: $b=a$ at evaluation of response.

$\| \mathbf{M S}=$ morning stiffness.

Patient characteristics and data on the reaction to parenteral gold are presented in Tables 1 and 2 respectively.

\section{SIB PAIR I (TWO SISTERS)}

Patient No 1 developed rheumatoid arthritis at the age of 53 and failed to respond to non-steroidal antiinflammatory drugs (NSAIDs). At the age of 54 treatment with aurothioglucose was started. After $250 \mathrm{mg}$ of parenteral gold she developed a rash necessitating stopping the treatment. At this time there were only minimal signs of arthritis. The rash disappeared within one month. Patient No 2, her elder sister, developed rheumatoid arthritis at the age of 54. Treatment with NSAIDs and hydroxychloroquine was not successful. At the age of 58 treatment with aurothioglucose was instituted. After $850 \mathrm{mg}$ of the drug, given over a period of three months, she developed a maculopapular rash and treatment had to be stopped. Thereafter, the rash gradually disappeared. At the time of the rash her rheumatoid arthritis was quiescent.

SIB PAIR II (BROTHER AND SISTER)

Patient No 3 developed rheumatoid arthritis at the age of 53. At first he had been treated with NSAIDs and hydroxychloroquine, which was initially effective but subsequently did not control disease 
activity. At the age of 58 years gold therapy was instituted. After four months he developed dermatitis and a slight stomatitis, and gold was stopped. At that time there was no evident disease activity. Approximately five and a half years later gold was reinstituted because of a disease flare. This treatment had to be stopped after a cumulative dose of $500 \mathrm{mg}$ because of a rash.

Clinical response was good, though some residual swelling of the joints was present. Patient No 4, his elder sister, developed rheumatoid arthritis at the age of 71 . She was initially treated with NSAIDs and hydroxychloroquine, without clinical effect. At the age of 72 gold therapy was started; after four months of treatment there were no signs of active arthritis. At the cumulative does of $1100 \mathrm{mg}$ she had a moderately severe dermatitis, and gold was stoped. There were no signs of disease activity at that time. Because of a flare, gold was reinstituted one and a half years later. After three months of therapy the disease was in remission, but after a total dose of $800 \mathrm{mg}$ (over nine months) she developed dermatitis again, necessitating stopping the treatment. At that stage there was evidence of only slight disease activity.

\section{Discussion}

This report shows remarkably similar reactions to parenteral gold therapy in two sib pairs, in terms of both toxicity and favourable clinical response to the drug. Tissue typing showed that the sib pairs were HLA identical. Toxicity on parenteral gold therapy has been found in some studies to be associated with certain HLA antigens, namely HLA-B8 and DR3. ${ }^{27-10}$ These associations were predominantly found for gold induced proteinuria ${ }^{8}$ and thrombocytopenia. 9 10 ${ }^{10}$ Interestingly, an association between the most frequent side effect, i.e., skin rash, and HLA antigens has been found in only a few studies. ${ }^{211} 12$ Bardin et al found an association with the haplotype A1 Cw7 B8 DR3, ${ }^{11}$ and our group has recently reported an association with HLA-B8 and DR3. ${ }^{12}$ It should be stressed, however, that other groups have been unable to find associations between HLA antigens and gold toxicity. ${ }^{1314}$

The patients in these two sibships developed the same pattern of toxicity and in addition, showed the same favourable clinical response to the drug. One of the sib pairs possessed the haplotype HLA-B8 and DR3; antigens that have been associated with both gold toxicity ${ }^{127-11}$ and excellent clinical re- sponse. $^{3} 12$ The other sib pair, however, did not possess these antigens. Both patients of the latter sib pair received two courses of gold and on each occasion reacted identically to this treatment. This observation suggests that other genetic factors associated with chromosome 6 may have a role in the reaction to parenteral gold therapy.

Although suggestive, the present data are anecdotal and need to be confirmed by more extensive studies. There is, however, accumulating evidence $\vec{\circ}$ that genetic factors have a role in the way patients react to antirheumatic drugs, in terms of both side effects and efficacy.

\section{References}

1 Panayi G S. Wooley P. Batchelor J R. Genetic hasis of rheumatoid disease: HLA antigens, disease manifestations and toxic reactions to drugs. $\mathrm{Br}$ Med J 1978; ii: 1326-8.

2 Bensen W G. Moore N. Tugwell P. D Souza M. Singal D P. HLA antigens and toxic reactions to sodium aurothiomalate in patients with rheumatoid arthritis. J Rheumatol 1984: 11: $358-61$.

3 van Ricl P L C M. Reckers P. van de Putte L B A. Gribnau F W J. Association of HLA antigens, toxic reactions and therapeutic response to auranofin and aurothioglucose in patients with rheumatoid arthritis. Tissue Antigens 1983; 22: 194-9.

4 O’Duffy J D. O'Fallon W M. Hunder G G, McDuffic F C Moore S B. An attempt to predict the response to gold therap in rheumatoid arthritis. Arthritis Rheum 1984: 27: 1210-7.

5 Ropes M W. Bennett G A. Cobbs S. Jacox R. Jessar R A. 19 revision of diagnostic criteria for rheumatoid arthritis. But+ Rheum Dis 1958: 9: 175-6.

6 Mallya R K. Mace B E W. The assessment of disease activity in rheumatoid arthritis using a multivariate analysis. Rheumatol Rehabil 1981; 20: 14-7.

7 Wooley P H. Griffin J. Panavi G S. Batchelor J R. Welsh K I. Gibson T J. HLA-DR antigens and toxic reactions to sodium aurothiomalate and D-penicillamine in rheumatoid arthritis. $N$ Engl J Med 1980: 300: 3(0)-2

8 Gran J T. Husby G. Thorsby E. HLA-DR antigens and gold toxicity. Ann Rheum Dis 1983: 42: 63-6.

9 Coblyn J S. Weinblatt M. Holdsworth D. Glass D. Goldinduced thrombocytopenia. A clinical and immunogenetic study on twenty-three patients. Ann Intern Med 1981; 95: 178-81.

10) Speerstra F. Reckers P, van de Putte L B A. Vandenbroucke J P. HLA associations in aurothioglucose and D-penicillamine induced haematotoxic reactions in rheumatoid arthritis. Tissue Antigens 1985; 26: 35-40.

11 Bardin T, Dryll A, Debeyre N, et al. HLA system and side effects of gold salts and D-penicillamine treatment of rheumatoid arthritis. Ann Rheum Dis 1983; 42: 63-6.

12 Speerstra F. van Riel P L C M. Reekers P. van de Putte L B A. Vandenbroucke J P. collaborating clinics. The influence of HLA phenotypes on the response to parenteral gold in rheumatoid arthritis. Tissue Antigens (in press).

13 Stastny $\mathrm{P}$. Joint report rheumatoid arthritis. In: Terasaki PI. ed. Histocompatability testing. Los Angeles: UCLA Tissue Typing Laboratory, 1980: 681-6.

14 Dequeker J, van Wanghe P. Verdickt W. A systemic survey of HLA A. B, C and D antigens and drug toxicity in rheumatoid arthritis. $J$ Rheumatol 1984; 11 : 282-6. 